\title{
Tracking the Fate of Fertilizer Nitrogen in a Paddy Rice Field Using Isotope Technology
}

\author{
Xiangfei Yu${ }^{1,2}$, Yingying $\mathrm{Xu}^{3}$, Hui Zhu ${ }^{1^{*}}$, Brian Shutes ${ }^{4}$, Baixing Yan ${ }^{\text {1**}}$, \\ Xin Chen ${ }^{1}$, Rui Cheng ${ }^{1}$ \\ ${ }^{1}$ Key Laboratory of Wetland Ecology and Environment, Northeast Institute of Geography and Agroecology, \\ Chinese Academy of Sciences, Changchun, P.R. China \\ ${ }^{2}$ University of Chinese Academy of Sciences, Beijing, P.R. China \\ ${ }^{3}$ Key Laboratory of Songliao Aquatic Environment, Ministry of Education, Jilin Jianzhu University, \\ Changchun, P.R. China \\ ${ }^{4}$ Urban Pollution Research Centre, Middlesex University, Hendon, London, United Kingdom
}

Received: 12 October 2018

Accepted: 19 January 2019

\begin{abstract}
The aim of this study was to track the fate of nitrogen derived from fertilizer $\left(\mathrm{N}_{\mathrm{dff}}\right)$ after fertilization. A field in situ experiment covering an entire growing season by using ${ }^{15} \mathrm{~N}$-doubly-labelled urea as fertilizer was conducted at a paddy field inSanjiang Plain in northeastern China. Results showed that approximately $70 \%$ of total nitrogen (TN) output load was from $\mathrm{N}_{\mathrm{dff}}$ and the lateral seepage contributed $\sim 47 \%$ and $\sim 40 \%$ of $\mathrm{TN}$ and $\mathrm{N}_{\mathrm{dff}}$ output loads, and the rest of the $\mathrm{TN}$ and $\mathrm{N}_{\mathrm{dff}}$ output loads were derived from runoff and artificial drainage. The $\mathrm{N}_{\mathrm{dff}}$ contents in paddy root, stalk, foliage and kernel increased with increasing fertilization dosages - from the tillering stage to mature stage. $\mathrm{N}_{\mathrm{dff}}$ accumulated in the root, stalk and foliage during tillering and the milk stage migrated to the kernel in the mature stage. Most of the residual $\mathrm{N}_{\mathrm{dff}}$ in soil was distributed in the top layer $(0-10 \mathrm{~cm})$. Crop utilization and gaseous loss were the main fates of $\mathrm{N}_{\mathrm{dff}}$ in the paddy field. The proportion of crop utilization with an average value of $\sim 37 \%$ increased from $30.29 \%$ to $43.52 \%$ with increasing fertilization dosages, while the proportion of gaseous loss decreased from $49.61 \%$ to $32.74 \%$ with increasing fertilization dosages. $180 \mathrm{~kg} \mathrm{~N} \mathrm{hm}^{-2}$ was the optimum fertilization dosage for crop utilization rate and non-point source pollution control in the rice-growing area of Sanjiang Plain.
\end{abstract}

Keywords: nitrogen fertilizer balance, non-point source pollution, paddy rice field, lateral seepage, nitrogen fate

*e-mail: zhuhui@iga.ac.cn

**e-mail: yanbx@iga.ac.cn 


\section{Introduction}

Rice (Oryza sativa L.) is one of the staple crops, and its production accounted for $28.26 \%$ of total cereal yield in the world in 2017, according to data from the Food and Agriculture Organization (FAO) of the United Nations $[1,2]$. Nitrogen $(\mathrm{N})$ is the most vital nutrient element limiting the growth of paddy rice, and the application of nitrogen fertilizer strongly affects paddy rice yield $[3,4]$. As a result, annual nitrogen fertilizer consumption by paddy rice has constantly increased to 15.56 million tonnes around the world by 2014, which accounted for $15.18 \%$ of annual total nitrogen fertilizer consumption [5].

However, fertilizer nitrogen could not be completely utilized by the paddy rice. Only about $50-80 \%$ of nitrogen could be utilized under field experiments with good fertilizer management [6,7], while the nitrogen utilization rate in practical cultivation could be as low as $30 \%[8,9]$. The major pathways for nitrogen loss from paddy rice field via water include the surface runoff occurring with heavy rainfall, artificial drainage, and the underlying vertical or lateral leaching [10-16]. The direct discharge of drainage water containing nitrogen into the receiving water bodies might cause serious agricultural-derived non-point source (NPS) pollution [17-21]. The gaseous loss of nitrogen usually consists of the following two pathways: 1) the unstable $\mathrm{NH}_{4}^{+}$ ion can be slowly converted into $\mathrm{NH}_{3}$ and volatilized into the atmosphere; 2) some of the unused $\mathrm{NH}_{4}^{+}$can be converted into $\mathrm{N}_{2} \mathrm{O}$ or $\mathrm{N}_{2}$ through nitrification, denitrification and anaerobic oxidation of ammonium (anammox) [15, 22-25]. There is also a small amount of residual nitrogen remaining in the soil layer, which will ultimately be mineralized and immobilized by soil microorganisms [10]. Previous studies have investigated the migration and transformation of fertilizer nitrogen in paddy rice fields. For example, Yang et al. (2015) reported that $0.6-15 \%$ of the $\mathrm{N}_{2}$ emissions from soil was contributed by the anammox process in southern China, which dissipated around $10 \%$ of fertilizer $\mathrm{N}$ [22]. Ji et al. (2011) analyzed the nitrogen leaching capacities of three types of paddy rice soil in Dongting Lake Area and indicated that the organic nitrogen and ammonia nitrogen were the main forms of nitrogen in the leaching water and the amount of fertilizer nitrogen in the leaching water accounted for $0.66-2.28 \%$ of the total nitrogen applied [26]. Zhu et al. (2013) found that lateral seepage could contribute more than $35 \%$ of nitrogen output load for near trench paddy field [12]. Although great efforts have been made to investigate the fate of fertilizer nitrogen in paddy rice fields, a comprehensive understanding of environmental behavior of fertilizer nitrogen is limited due to the lack of mass balance measurement involving multiple pathways (i.e., plant uptake, NPS output, soil residue, and gaseous loss). Furthermore, it was quite difficult to precisely quantify the environmental behavior of fertilizer nitrogen in a paddy rice field if the interference of background value of soil nitrogen was not eliminated.

${ }^{15} \mathrm{~N}$ is another existent form of element nitrogen apart from ${ }^{14} \mathrm{~N}$. It has nearly the same physical and chemical characteristics as ${ }^{14} \mathrm{~N}$. When the ${ }^{15} \mathrm{~N}$ tracer was applied into a specific ecosystem, the amount and distribution of ${ }^{15} \mathrm{~N}$ in different environmental media (e.g. atmosphere, plant, microorganism, water and soil) could be quantified by using an isotope ratio mass spectrometer (IRMS) [27-31]. Therefore, ${ }^{15} \mathrm{~N}$ tracing technology was widely applied to reveal the nitrogen behavior in the environment. For example, ${ }^{15} \mathrm{~N}$ tracer has been used for screening the optimal manure and fertilization patterns and evaluating different types of paddy rice fields based on nitrogen uptake efficiency [29, 31-33]. In view of the advantage of isotope tracing technology and the above-successful case studies, it is theoretically feasible to more precisely quantitatively analyze the fate of fertilizer nitrogen.

The overall goal of this study was to track the fate of fertilizer nitrogen in a paddy rice field in Sanjiang Plain, China by using ${ }^{15} \mathrm{~N}$ tracer. The specific objectives were: 1 . to reveal the effects of fertilization dosages on nitrogen concentration in field water and lateral seepage water; 2. to evaluate the contribution of fertilizer nitrogen to the NPS pollution output; 3. to quantify the distribution characteristics of fertilizer nitrogen in paddy tissues and paddy field soil profile; and 4. to quantify the fate of fertilizer nitrogen,including crop utilization, gaseous loss, NPS output load and soil residue in the entire paddy field environment. The results obtained from this study will provide reference for improving the tillage method and mitigating the agricultural NPS pollution.

\section{Material and Methods}

\section{Description of the Study Site}

A plot scale experiment was conducted at the experimental plot of Sanjiang Mire Wetland Experimental Station of Chinese Academy of Sciences (CAS), which is located in Sanjiang Plain in northeastern China. Sanjiang Plain is a low-lying fluvial plain via the scour of the Amur, Songhua and Ussuririvers. The covering area of Sanjiang Plain is $1.089 \times 10^{5} \mathrm{~km}^{2}$, which accounts for $22.8 \%$ of the total area of Heilongjiang Province. The climate and characteristics of soil at the experimental site adequately represent the regionalism of Sanjiang Plain. The mean annual precipitation and mean annual temperature of the experimental site is $600 \mathrm{~mm}$ and $1.4-4.3^{\circ} \mathrm{C}$, respectively. The soil type of the experimental site was albic soil and the particulate composition of soil was sand $(6.25 \%)$, silt (30.68\%) and clay $(63.07 \%)$, and its chemical properties for total organic carbon (TOC), $\mathrm{pH}(1: 2.5 \mathrm{KCl})$, total nitrogen (TN), total phosphorus (TP) and cation exchange capacity (CEC) were $2.58 \%, 6.85,0.20 \%, 0.04 \%$ and 


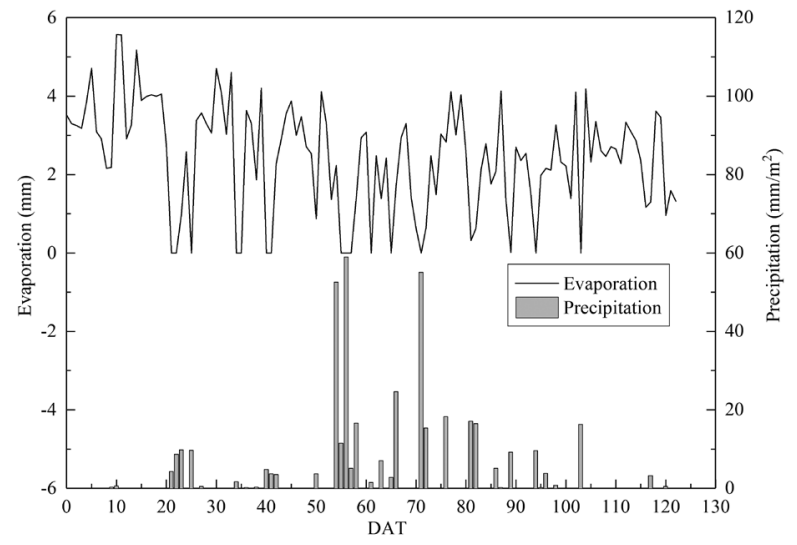

Fig. 1. The evaporation and precipitation data of the experimental site during the experimental period. DAT: days after transplantation.

$29.03 \mathrm{cmol}(+) \mathrm{kg}^{-1}$, respectively. The evaporation and precipitation data of the experimental site during the experimental period are shown in Fig. 1.

\section{Field Experiment}

The experiment was conducted from May to September 2011, which covered an entire growing season of the paddy rice. Twelve plots of $1 \times 1 \mathrm{~m}$ were set up at the boundary of a near-trench paddy field. One side of each plot overlapped with the bund of the paddy field (Fig. 2), and the other three sides of each plot were completely insulated from the surroundings by plastic partition boards that were inserted into the clay pan to avoid the interchange of subsurface water. The bund with $0.4 \mathrm{~m}$ in width was installed with a lateral seepage water collector on the trench side for each plot (Fig. 2). Permeable formwork cloth and top-caps were fitted to the collectors to separate soil particles and block the sunlight. The same design of collectors was applied in our previous research [12].
A native paddy rice cultivar was transplanted into each experimental plot in accordance with the local farming habit on May 26 2011. The ${ }^{15} \mathrm{~N}$-doubly-labelled urea $(20.1 \%$ in abundance, manufactured by Shanghai Research Institute of Chemical Industrial, China) was applied into the plots as nitrogen fertilizer. There were four treatments with the total fertilizing dosages of $0 \mathrm{~kg} \mathrm{~N} \mathrm{hm}{ }^{-2}, 90 \mathrm{~kg} \mathrm{~N} \mathrm{hm}^{-2}, 180 \mathrm{~kg} \mathrm{~N} \mathrm{hm}^{-2}$ (recommended fertilization dosage) and $270 \mathrm{~kg} \mathrm{~N} \mathrm{hm}^{-2}$, respectively. Sixty percent of nitrogen fertilizer was applied 9 days after transplantation (DAT) as the basic fertilizer, $\mathrm{P}_{2} \mathrm{O}_{5}$ and $\mathrm{KCl}$ were also added to the basic fertilizer with the amount of $40 \mathrm{~kg} \mathrm{P} \mathrm{hm}^{-2}$ and $150 \mathrm{~kg} \mathrm{~K} \mathrm{hm}^{-2}$, respectively, as the anthropogenic phosphorus $(\mathrm{P})$ and potassium $(\mathrm{K})$ sources. The remaining $40 \%$ of the nitrogen fertilizer was applied at the beginning of the tillering stage on 35 DAT. The water level in each plot remained between $4 \mathrm{~cm}$ and $10 \mathrm{~cm}$ before drying the field (on $75 \mathrm{DAT}$ ). There were three parallel plots for each treatment.

\section{Sample Collection}

Water samples included paddy water, storm runoff water, artificial drainage water and lateral seepage water. Paddy water and lateral seepage water samples were collected daily in the first 5 days after fertilization, which occurred on 9 DAT and 35 DAT, respectively. The sampling frequency was reduced to once per 2-12 days since day six after fertilization. An electric capacity liquidometer (Odyssey, New Zealand) was set in the paddy field to record the real-time water level. Water samples of storm runoff and artificial drainage were collected when they occurred. All the water samples were filtered through a $0.45 \mu \mathrm{m}$ filter membrane before analysis. Three paddy samples were collected in each plot at tillering stage (34 DAT), milk stage (75 DAT) and mature stage (122 DAT), respectively. All the paddy samples were thoroughly cleaned by deionized water and then separated into root, stalk, foliage and kernel

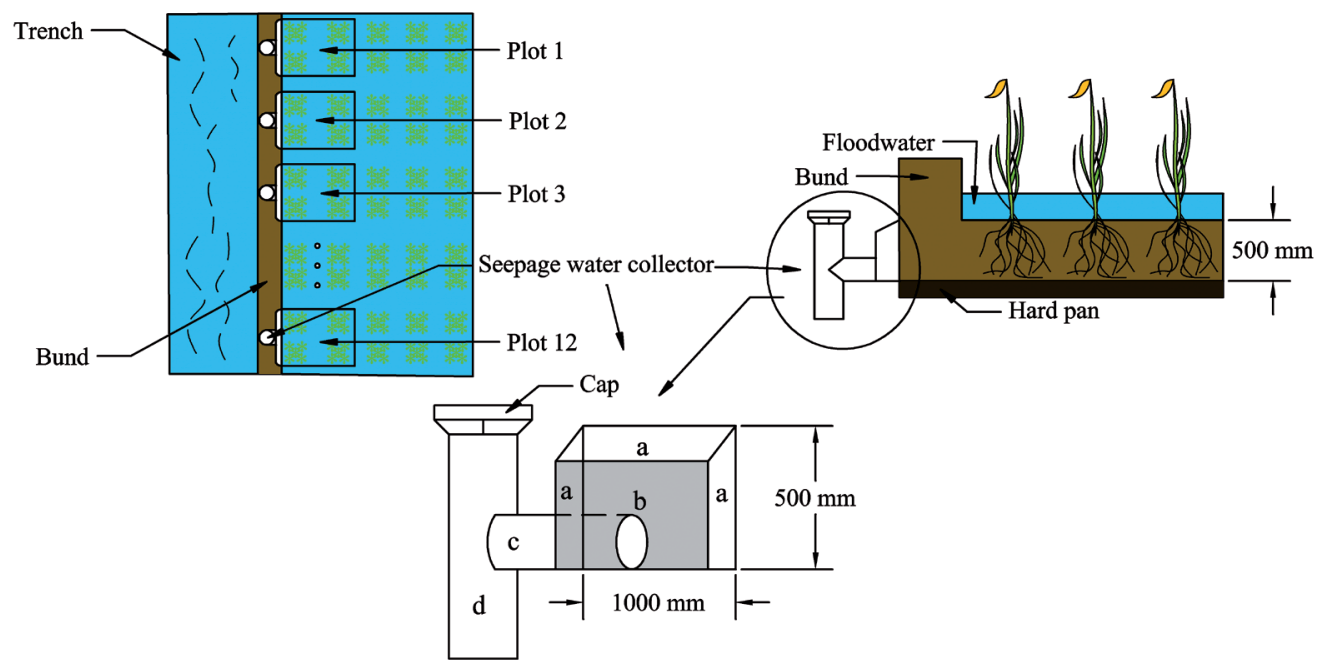

Fig. 2. Sketch of the seepage water collector. a: the insert board, b: the suck-surface. c: the transport tube, d: the container. 
(only for samples at milk and mature stages). The subsamples were dried at $60^{\circ} \mathrm{C}$ and weighed and ground to a fine powder for digestion, as described below. Three soil samples were collected from each plot after harvesting with five profile depths: $0-10 \mathrm{~cm}, 10-20 \mathrm{~cm}, 20-30 \mathrm{~cm}$, $30-40 \mathrm{~cm}$ and $40-50 \mathrm{~cm}$, respectively. The soil samples were air-dried, ground and sieved through a $150 \mu \mathrm{m}$ sieve for digestion, as described below.

\section{Sample Analysis}

The TN in soil and paddy samples was converted into ammonium nitrogen by acid digestion for analysis. Soil samples with weight of $0.2 \mathrm{~g}$ were digested with $5 \mathrm{~mL}$ sulfuric acid and 10 drops of perchloric acid in the digestion tube at $280^{\circ} \mathrm{C}$. When the digestive solution became colorless and transparent, we increased the digestion temperature to $370^{\circ} \mathrm{C}$ and maintained for an hour therewith cooling to room temperature. Paddy samples with the same weight were digested with $5 \mathrm{~mL}$ sulfuric acid and $4 \mathrm{~mL}$ hydrogen peroxide in the digestion tube at $370^{\circ} \mathrm{C}$ for seven minutes and cooled to room temperature. We repeated the digestion with additional $2 \mathrm{~mL}$ hydrogen peroxide until the digestive solution became colorless and transparent. The digestive solutions of soil and paddy samples were filtered with $0.45 \mu \mathrm{m}$ filter membrane and then diluted to $500 \mathrm{~mL}$ with deionized water. The ammonium nitrogen in the diluted digestive solutions was determined by the U.S. Environmental Protection Agency (EPA) 350.1. TN concentrations of water samples were determined according to EPA $351.2 .{ }^{15} \mathrm{~N}$ abundances in soil and plant samples were analyzed by IRMS (Sercon Integra $2 \mathrm{CN}$, UK).

\section{Data Processing and Statistical Analyses}

The volumes of runoff and artificial drainage were quantified by Eq. 1 and Eq. 2. The quantification of lateral seepage water was determined by Eq. 3 from the method of Yang et al. (2015b) and Huang et al. (2003) $[34,35]$. It is noteworthy that vertical leaching was not calculated in this study due to the low permeability $\left(<0.2 \mathrm{~mm} \mathrm{~d}^{-1}\right)$ of paddy soil in Sanjiang Plain [36].

$$
\begin{gathered}
R=S \times(P \times S-B+F) \\
D=S \times \Delta F \\
L S=S \times(\Delta F+I+P \times S-E)-D-R
\end{gathered}
$$

...where $R$ is the volume of runoff water, $\mathrm{m}^{3} ; P$ is precipitation, $\mathrm{mm} \mathrm{m}^{-2} ; S$ is the area of experimental plot, $\mathrm{m}^{2} ; B$ is the height of the paddy field bund, $\mathrm{m} ; F$ is the water level of paddy field; $D$ is the volume of artificial drainage water, $\mathrm{m}^{3} ; L S$ is the volume of lateral seepage water, $\mathrm{m}^{3} ; I$ is the height of irrigation water, $\mathrm{mm} ; P$ is the volume of precipitation, $\mathrm{mm}$; and $E$ is the volume of evapotranspiration, $\mathrm{mm}$.
The rates and contents of nitrogen derived from fertilizer $\left(\mathrm{N}_{\mathrm{dff}}\right)$ in water, plant and soil were calculated by Eqs. 4-9, respectively [29, 33, 37]. The nitrogen fertilizer efficiency was acquired by Eq. 10 [29]. The $\mathrm{N}_{\mathrm{dff}}$ interception rate of field bund was obtained by Eq. 11.

$$
\text { water } N_{d f f} \text { rate }=\frac{\text { at. } \%{ }^{15} \mathrm{~N} \text { excess of water }}{\text { at. } \%{ }^{15} \mathrm{~N} \text { excess of fertilizer }} \times 100 \%
$$

$$
\text { water } N_{d f f} \text { content }=\text { water } N_{d f f} \text { rate } \times N_{\text {water }}
$$

plant $N_{d f f}$ rate $=\frac{\text { at. } \%{ }^{15} \mathrm{~N} \text { excess of plant }}{\text { at. } \%{ }^{15} \mathrm{~N} \text { excess of fertilizer }} \times 100 \%$

$$
\begin{gathered}
\text { plant } N_{d f f} \text { content }=\text { plant } N_{d f f} \text { rate } \times N_{\text {plant }} \\
\text { soil } N_{d f f} \text { rate }=\frac{\text { at. } \%{ }^{15} N \text { excess of soil }}{\text { at. } \%{ }^{15} N \text { excess of fertilizer }} \times 100 \%
\end{gathered}
$$

$$
\begin{gathered}
\text { soil } N_{d f f} \text { content }=\text { soil } N_{d f f} \text { rate } \times N_{\text {soil }} \\
\eta_{\text {fertilizer }}= \\
\frac{m_{\text {Plant }} \times \text { plant } N_{d f f} \text { content } \times \text { at. } \%{ }^{15} N \text { excess of plant }}{m_{\text {fertilizer }} \times N_{\text {fertilizer }} \text { content } \times \text { at. } \%{ }^{15} N \text { excess of fertilizer }} \\
\times 100 \%
\end{gathered}
$$

$$
\begin{gathered}
N_{d f f} \text { interception rate }= \\
\frac{N_{d f f} \text { of field water }-N_{d f f} \text { of lateral seepage water }}{N_{d f f} \text { of field water }} \times 100 \%
\end{gathered}
$$

...where water $N_{d f f}$ rate is the rate of ${ }^{15} \mathrm{~N}$ derived from fertilizer in water, $\%$; water $N_{d f f}$ content is the content of ${ }^{15} \mathrm{~N}$ derived from fertilizer in water, $\mathrm{mg} \mathrm{kg}^{-1} ; N_{\text {water }}$ is the nitrogen content of water, $\mathrm{mg} \mathrm{L}^{-1}$; plant $N_{d f f}$ rate is the rate of ${ }^{15} \mathrm{~N}$ derived from fertilizer in plant, $\%$; plant $N_{d f f}$ content is the content of ${ }^{15} \mathrm{~N}$ derived from fertilizer in plant, $\mathrm{mg} \mathrm{kg}^{-1} ; N_{\text {plant }}$ is the nitrogen content of plant, $\mathrm{mg} \mathrm{kg}{ }^{-1}$; soil $N_{d f f}$ rate is the rate of ${ }^{15} \mathrm{~N}$ derived from fertilizer in soil, \%; soil $N_{d f f}$ content is the content of ${ }^{15} \mathrm{~N}$ derived from fertilizer in soil, $\mathrm{mg} \mathrm{kg}^{-1} ; \eta_{\text {fertilizer }}$ is the efficiency of nitrogen fertilizer; $m_{\text {plant }}$ is the weight of plant, $\mathrm{kg} ; m_{\text {fertilizer }}$ is the weight of fertilizer, $\mathrm{kg}$; $N_{\text {fertilizer }}$ content is the nitrogen content of fertilizer, $\mathrm{mg} \mathrm{kg} \mathrm{kg}^{-1} ; N_{d f f}$ of field water is the ${ }^{15} \mathrm{~N}$ concentration of field water, $\mathrm{mg} \mathrm{L}^{-1}$; and $N_{d f f}$ of lateral seepage water is the ${ }^{15} \mathrm{~N}$ concentration of lateral seepage water, $\mathrm{mg} \mathrm{L}^{-1}$.

The Tukey-Kramer test (T-test) and one-way Anova test at the 0.05 level with LSD and Tukey HSD (for multiple comparisons) were applied to determine the significance of differences between different 
treatments. Regression analysis was adopted to explore the relationship between the $\mathrm{N}_{\text {dff }}$ residual contents in soil and soil depths. Calculations were conducted by Microsoft Office Excel and IBM SPSS Statistics version 23. All the figures were prepared by Origin 9.0.

\section{Results and Discussion}

\section{Effects of Fertilization Dosages on $\mathrm{N}_{\text {dff }}$ Concentration in Field Water and Lateral Seepage Water}

As shown in Fig. 3a, $\mathrm{N}_{\mathrm{dff}}$ concentrations in the field water of the three fertilization dosage treatments increased to peak concentrations on DAT 9 and DAT 35, immediately after the two fertilization activities respectively, followed by a sharp decrease in the following 2 days and then gradually approached to a steady value at $\sim 1.5 \mathrm{mg} \mathrm{L}^{-1}$ in the following 3 days. The first peak concentrations of 90, 180 and $270 \mathrm{~kg} \mathrm{~N} \mathrm{hm}{ }^{-2}$ treatments were 47.7, 96.0 and $121.9 \mathrm{mg} \mathrm{L}^{-1}$, respectively, while the second peak concentrations were $20.4,46.0$ and $43.9 \mathrm{mg} \mathrm{L}^{-1}$, respectively. In general, peak concentrations increased with the increasing fertilization dosages except for the second peak concentrations, when fertilization dosages increased from 180 to $270 \mathrm{~kg} \mathrm{~N} \mathrm{hm}^{-2}$. This observation might be explained by the following reason: the concentration difference between field water and percolating water enhanced the migration of $\mathrm{N}_{\text {dff }}$ to lateral seepage water (Fig. 3b) and to deep soil layer (Fig. 7).

Peak values of $\mathrm{N}_{\mathrm{dff}}$ concentrations in the lateral seepage water appeared within 3 days after each fertilization activity and the concentrations slowly decreased to a stable and low level in the following 15 days (Fig. 3b). This observation agreed with the report of Zhao et al. (2014) and Liang et al. (2008) $[38,39]$. In general, the loss of $\mathrm{N}_{\mathrm{dff}}$ via lateral seepage mainly happened in the following 5 days after each fertilization activity. The first peak concentrations of the three dosages were $2.35,8.59$ and $14.42 \mathrm{mg} \mathrm{L}^{-1}$, for 90,180 and $270 \mathrm{~kg} \mathrm{~N} \mathrm{hm}^{-2}$ treatment, respectively, while the second peak concentrations were 3.68, 5.20 and $9.95 \mathrm{mg} \mathrm{L}^{-1}$ respectively. $\mathrm{N}_{\mathrm{dff}}$ peak concentrations in the lateral seepage water were significantly $(\mathrm{p}<0.05)$ lower than those in the field water. These results indicated that the paddy field bund not only intercepted the leakage of field water, but also mitigated the migration of $\mathrm{N}_{\mathrm{dff}}$ in the field. Unlike the slight influence of fertilization dosages on nitrogen concentration in vertical leachate reported by Yao et al. (2017) and Peng et al. (2011) $[1,40]$, the $\mathrm{N}_{\mathrm{dff}}$ peak concentrations of lateral seepage water observed in this study significantly $(\mathrm{P}<0.05)$ increased with increasing fertilization dosages. This was because the percolating water in the plow layer cannot pass through the underneath hardpan, the direction of percolation changed to cross-flow so that percolating water spread toward the adjacent field or bund [41].

In order to further reveal the effectiveness of the bund for intercepting $\mathrm{N}_{\mathrm{dff}}$ from paddy field to the adjacent ditches, the $\mathrm{N}_{\mathrm{dff}}$ interception rates were calculated for different treatments (Fig. 4). In the following 3 days after both fertilization activities (9 DAT and 35 DAT), the interception rates of the paddy field bund to $\mathrm{N}_{\mathrm{dff}}$ were maintained at a relatively high level with a range of 59.46-97.36\% without significant differences among the different fertilization dosages, demonstrating that the field bund exhibited a positive contribution to fertilizer utilization efficiency and agricultural NPS pollution control. Between the two fertilization activities (from 18 DAT to $34 \mathrm{DAT}$ ), the $\mathrm{N}_{\mathrm{dff}}$ interception rates exhibited negative values and the same phenomenon was observed for $270 \mathrm{~kg} \mathrm{~N} \mathrm{hm}^{-2}$ treatment from 41 DAT to 73 DAT. This was because a portion of $\mathrm{N}_{\text {dff }}$ accumulated in the bund soil might migrate back to the percolating water due to concentration differences. The percolating water horizontally migrated through the bund, which became lateral seepage water ultimately. However, at this
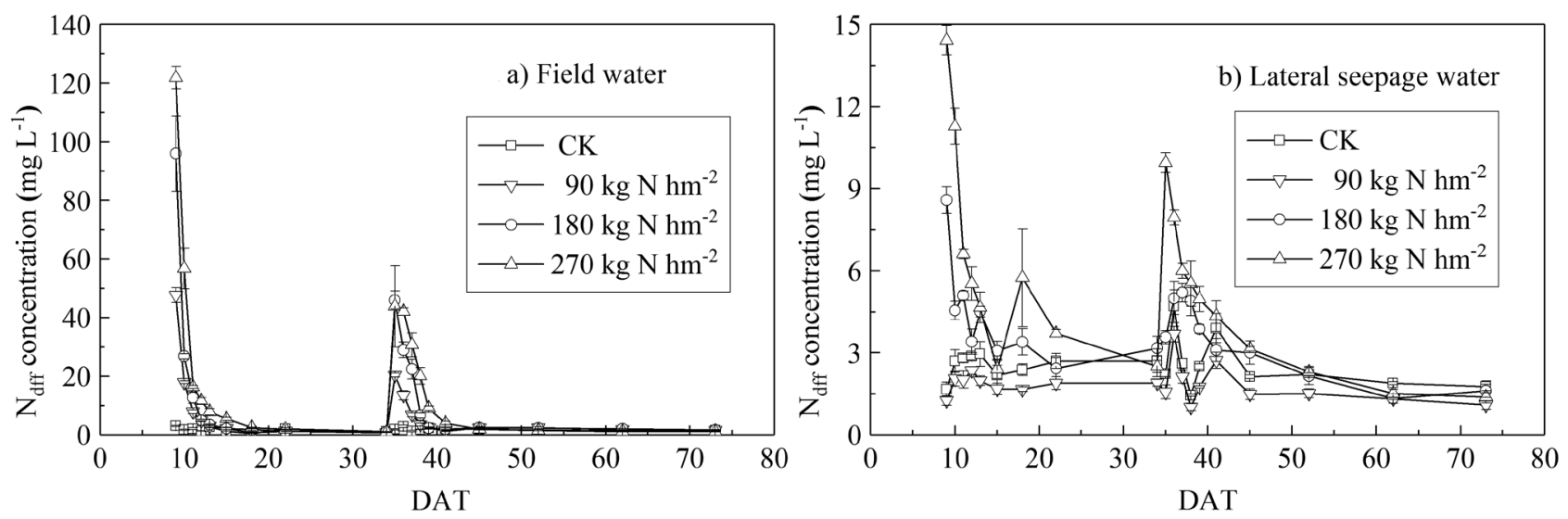

Fig. 3. $\mathrm{N}_{\mathrm{dff}}$ concentrations in field water and lateral seepage water under different fertilization dosages. a) field water. b) lateral seepage water. Values represent the mean of three replicates and error bars represent standard deviations. 


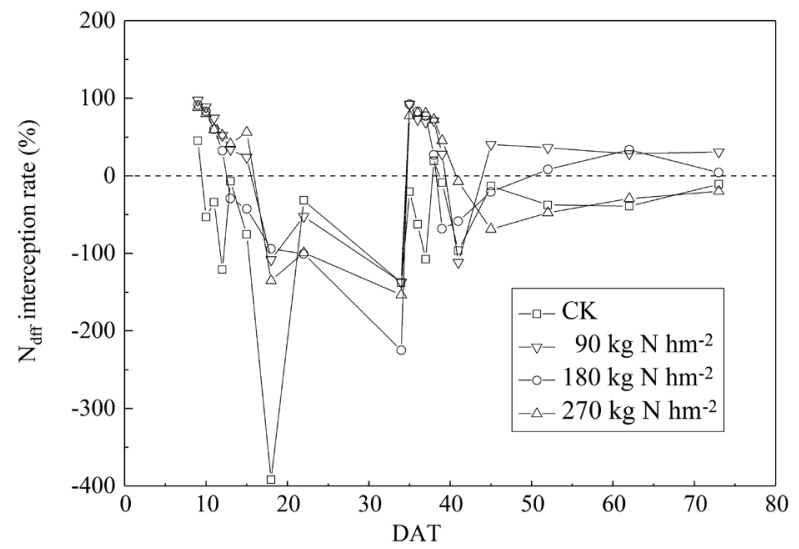

Fig. 4. $\mathrm{N}_{\mathrm{dff}}$ interception rates of bund soil under different fertilization dosages. Values represent the mean of three replicates.

period of time the $\mathrm{N}_{\mathrm{dff}}$ in lateral seepage water remained relatively stable at a low concentration $\left(\sim 2.43 \mathrm{mg} \mathrm{L}^{-1}\right)$. Based on the above analysis, the effects of fertilization dosages on $\mathrm{N}_{\mathrm{dff}}$ interception rate were slight, while bund type, physicochemical property of bund soil and bund age might play more significant roles in determining the $\mathrm{N}_{\text {dff }}$ interception rate $[35,42]$.

\section{Impact of Fertilization Dosages on NPS Pollution Load from Paddy Field}

As the soil below the $500 \mathrm{~mm}$-in-thickness plow layer in the paddy field formed a hardpan (shown in Fig. 2), which presented low permeability of paddy soil in Sanjiang Plain [36], the vertical migration of paddy field water can be neglected. Instead, paddy field water can only horizontally migrate along the interface of plow layer and hardpan and become lateral seepage water. In this research, annual output loads from three nitrogen output sources (i.e., lateral seepage, runoff and artificial drainage) were calculated (Fig. 5). Both $\mathrm{N}_{\mathrm{dff}}$ and $\mathrm{TN}$ output loads increased with increasing fertilizer dosages. The TN output loads under three fertilizer dosages were 7.82, 26.49 and $33.35 \mathrm{~kg} \mathrm{hm} \mathrm{yr}^{-1}$, respectively. Similar results were observed in a flooded paddy field with the nitrogen output load from 6.54 to $26.54 \mathrm{~kg} \mathrm{~N} \mathrm{hm}^{-2} \mathrm{yr}^{-1}$ at a fertilization dosage of $300 \mathrm{~kg} \mathrm{~N} \mathrm{hm}^{-2}$ (urea) [38]. Approximately 47\% of the TN output load was contributed by lateral seepage $\left(3.42,12.66\right.$ and $16.74 \mathrm{~kg} \mathrm{hm}^{-2} \mathrm{yr}^{-1}$, respectively), and the remaining $\mathrm{TN}$ output loads originated from runoff and artificial drainage. However, TN output loads include both nitrogen originating from annual fertilizer and other sources (e.g., soil residue and atmospheric sedimentation). Therefore, $\mathrm{N}_{\mathrm{dff}}$ output loads were introduced to further quantify the output of nitrogen originating from annual fertilization. The $\mathrm{N}_{\mathrm{dff}}$ output loads under three fertilizer dosages were 5.40, 18.16, and $23.68 \mathrm{~kg} \mathrm{hm}^{-2} \mathrm{yr}^{-1}$, respectively, which accounted

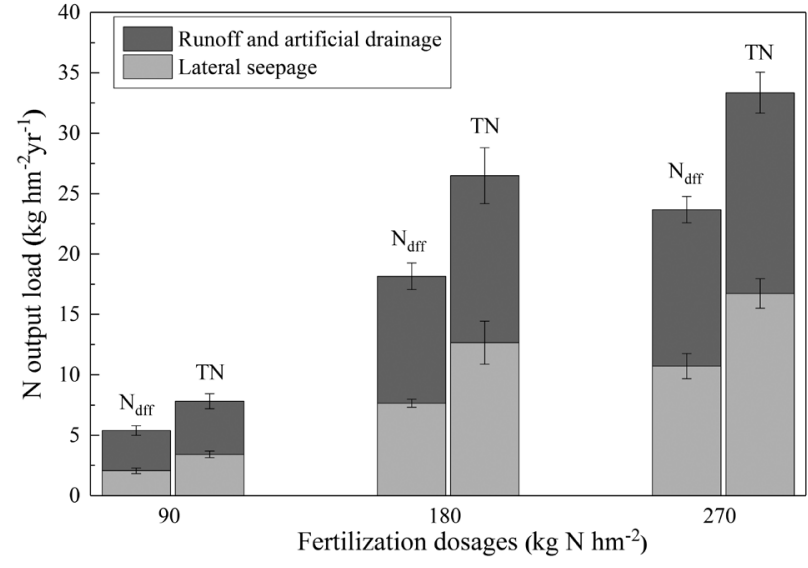

Fig. 5. Annual nitrogen output loads from the paddy field under different fertilization dosages. Values represent the mean of three replicates and error bars represent standard deviations.

for $\sim 70 \%$ of $\mathrm{TN}$ output load, indicating that the annual fertilization activity was the dominant source for NPS pollution. The $\mathrm{N}_{\mathrm{dff}}$ output loads from lateral seepage under three fertilizer dosages were 2.06, 7.65 and $10.72 \mathrm{~kg} \mathrm{hm}^{-2} \mathrm{yr}^{-1}$, respectively, which contributed $\sim 40 \%$ of the $\mathrm{N}_{\mathrm{dff}}$ output load. These observations demonstrated that lateral seepage was an important pathway for nitrogen loss from paddy fields and was a crucial process for nitrogen NPS pollution. For paddy soil with high permeability, vertical migration of paddy field water cannot be ignored [38], and 24-93\% of the nitrogen output could be derived from vertical leaching under specific conditions [29].

\section{$\mathrm{N}_{\mathrm{dff}}$ Absorption by Paddy Tissues}

The $\mathrm{N}_{\text {dff }}$ contents in different paddy tissues increased with increasing fertilization dosages for all the tested growth stages (Fig. 6a,c,e,g). At the tillering stage, $\mathrm{N}_{\mathrm{dff}}$ contents were less than $2 \mathrm{~g} \mathrm{~kg}^{-1}$ and the majority of $\mathrm{N}_{\mathrm{dff}}$ was accumulated in the foliage. With the growth of paddy, the $\mathrm{N}_{\mathrm{dff}}$ contents in root, stalk and foliage increased at the milk stage and then decreased (especially in foliage) at the mature stage. Although root was the medium for the direct absorption of $\mathrm{N}_{\mathrm{dff}}$ from soil, the majority of $\mathrm{N}_{\mathrm{dff}}$ was not accumulated in the root, and $\mathrm{N}_{\mathrm{dff}}$ in root, stalk and foliage migrated to the kernel which was the final receptor of $\mathrm{N}_{\text {dff* }}$. The above observation was in accordance with a study by Ghoneim et al. (2006) [43]. A comparison between the literature and this research indicated that the spatio-temporal variation of $\mathrm{N}_{\mathrm{dff}}$ content in plant tissues were not effectively impacted by external environmental factors (e.g., climate, soil type and farming habit, etc.) and plant cultivars. From the view of $\mathrm{N}_{\mathrm{dff}}$ absorption by paddy, $180 \mathrm{~kg} \mathrm{~N} \mathrm{hm}^{-2}$ was the optimal fertilization dosage. Excess fertilizer did not significantly enhance the $\mathrm{N}_{\mathrm{dff}}$ absorption capability of paddy tissues (Fig. 6g). As shown in Fig. 6(b,d,f,h), 
the $\mathrm{N}_{\mathrm{dff}}$ rate in different paddy tissues at all three growth stages fluctuated $7.70-39.42 \%$, indicating that most of the nitrogen absorbed by the paddy was from the soil residue, and only $17.18-30.83 \%$ of nitrogen in the kernel at the mature stage was from fertilizer (Fig. 6h). Similar rates were reported by Ghoneim et al. (2006) [43]. As an alternative, the application of improved rice cultivars with high nitrogen use efficiency might effectively increase the $\mathrm{N}_{\mathrm{dff}}$ rate in paddy tissue [44].
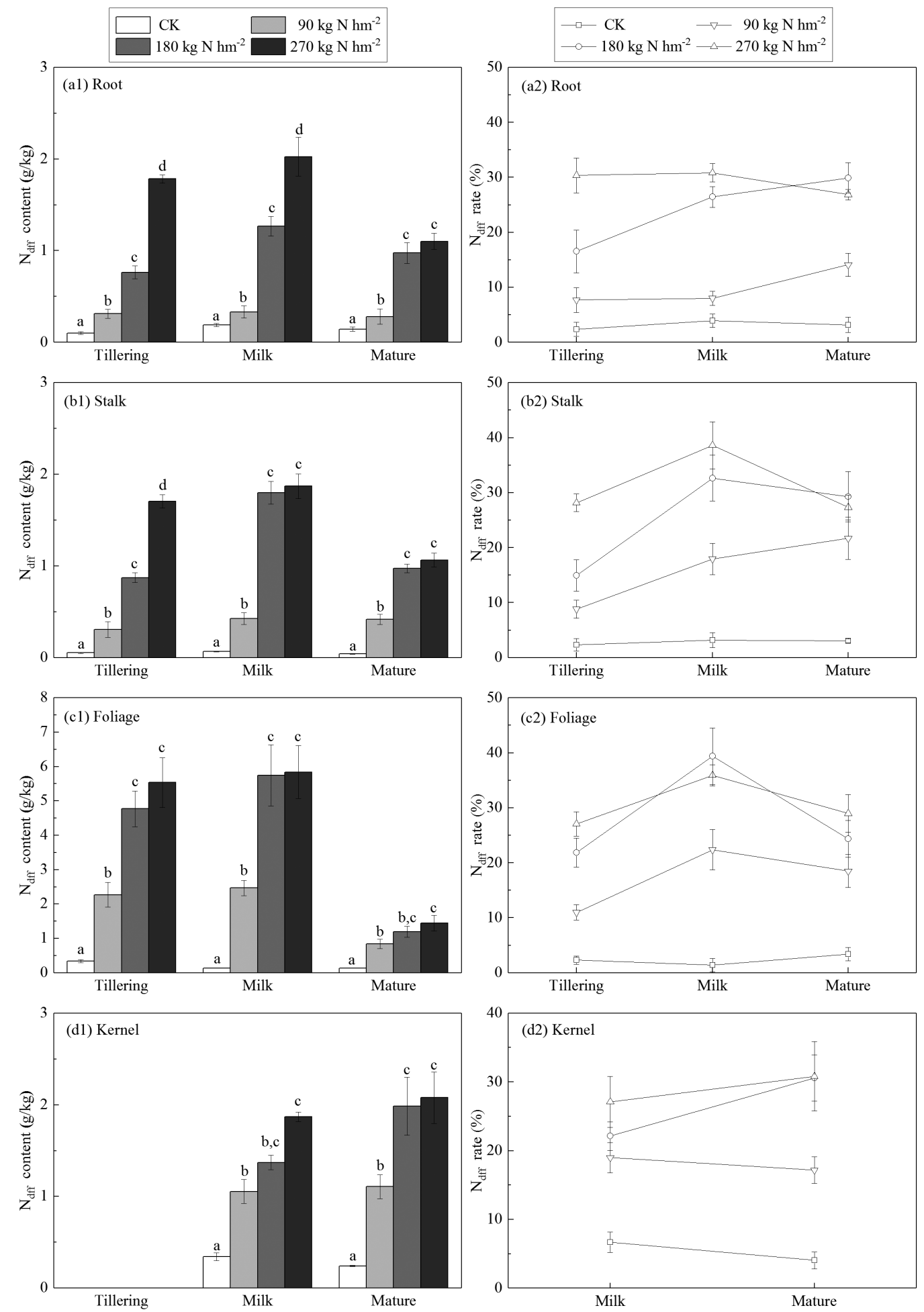

Fig. 6. $\mathrm{N}_{\mathrm{dff}}$ contents and rates in paddy tissues at different growth stages. (a1, b1, c1 and d1) $\mathrm{N}_{\mathrm{dff}}$ content in root, stalk, foliage and kernel, respectively. (a2, b2, c2 and d2) $\mathrm{N}_{\mathrm{dff}}$ rate in root, stalk, foliage and kernel, respectively. Values represent the mean of three replicates and error bars represent standard deviations. Columns containing different letters indicate significant differences among fertilization dosages on the same growth stage at $\mathrm{P}=0.05$. 


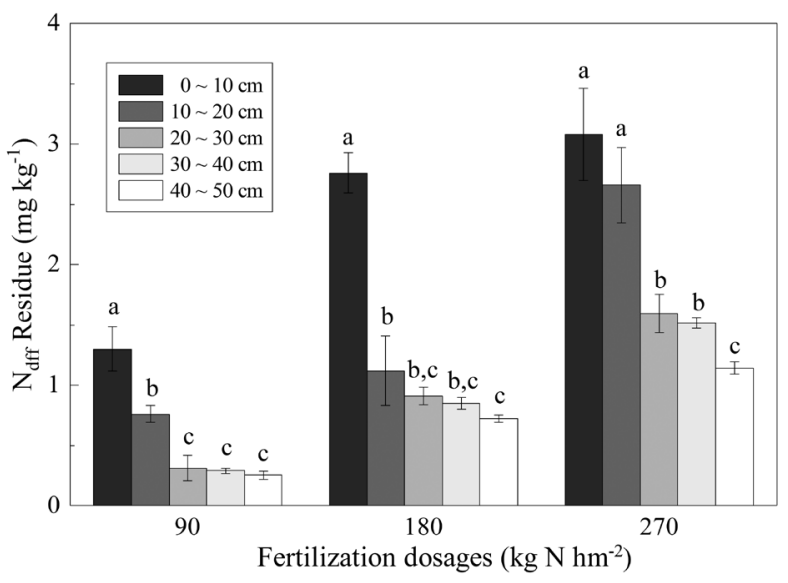

Fig. 7. Residue contents of $\mathrm{N}_{\mathrm{dff}}$ in paddy soil. Values represent the mean of three replicates and error bars represent standard deviations. Columns containing different letters indicate significant differences among soil depths on the same fertilization dosages at $\mathrm{P}=0.05$.

\section{Distribution of $\mathrm{N}_{\mathrm{dff}}$ in Different Depths of Soil}

$\mathrm{N}_{\mathrm{dff}}$ residue content in soil profiles with 5 depths were measured and plotted in Fig. 7. The peak content of $\mathrm{N}_{\mathrm{dff}}$ residue under three fertilization dosages were all observed in the top $(0-10 \mathrm{~cm})$ soil layer with the levels of $1.3\left(90 \mathrm{~kg} \mathrm{~N} \mathrm{hm}^{-2}\right), 2.8\left(180 \mathrm{~kg} \mathrm{~N} \mathrm{hm}^{-2}\right)$ and $3.1 \mathrm{mg} \mathrm{kg}^{-1}\left(270 \mathrm{~g} \mathrm{~N} \mathrm{hm}^{-2}\right)$, respectively, which accounted for $44.8 \%\left(90 \mathrm{~kg} \mathrm{~N} \mathrm{hm}^{-2}\right), 44.0 \%\left(180 \mathrm{~kg} \mathrm{~N} \mathrm{hm}^{-2}\right)$ and $31.0 \%\left(270 \mathrm{~kg} \mathrm{~N} \mathrm{hm}^{-2}\right)$ of the total $\mathrm{N}_{\mathrm{dff}}$ residue. The $\mathrm{N}_{\mathrm{dff}}$ residue content decreased with increasing soil depth. In the downward soil layer $(10-20 \mathrm{~cm})$, the $\mathrm{N}_{\mathrm{dff}}$ residue contents were more sensitively affected by the increase of the fertilization dosages compared with that of the deeper soil layer. The top two soil layers contributed to $71 \%\left(90 \mathrm{~kg} \mathrm{~N} \mathrm{hm}^{-2}\right), 61 \%\left(180 \mathrm{~kg} \mathrm{~N} \mathrm{hm}^{-2}\right)$ and $57.5 \%$ $\left(270 \mathrm{~kg} \mathrm{~N} \mathrm{hm}^{-2}\right)$ of the total $\mathrm{N}_{\mathrm{dff}}$ residue. The $\mathrm{N}_{\mathrm{dff}}$ residue content and fertilization dosages showed positive linear correlation in all depths, especially from 20 to $50 \mathrm{~cm}$. And the coefficients were $0.8797(0-10 \mathrm{~cm}), 0.8857$ $(10-20 \mathrm{~cm}), 0.9985(20-30 \mathrm{~cm}), 0.9977(30-40 \mathrm{~cm})$ and $0.9991(40-50 \mathrm{~cm})$, respectively. It could be seen from the above results that nitrogen appeared to be an active element and can migrate within at least $50 \mathrm{~cm}$ depth soil layer. A negative power regression between the $\mathrm{N}_{\mathrm{dff}}$ residue content and soil depth was observed with coefficients of $\left.0.9457(90 \mathrm{~kg} \mathrm{~N} \mathrm{hm})^{-2}\right), 0.9258$ $\left(180 \mathrm{~kg} \mathrm{~N} \mathrm{hm}^{-2}\right)$ and $0.9123\left(270 \mathrm{~kg} \mathrm{~N} \mathrm{hm}^{-2}\right)$, respectively.

$$
\text { Fates of } \mathrm{N}_{\mathrm{dff}}
$$

Crop utilization and gaseous loss (calculated by subtracting) were the major fates of $\mathrm{N}_{\mathrm{dff}}$, which accounted for more than $70 \%$ of the total fertilizer nitrogen (Fig. 8). With the increase of fertilization dosages, the proportion of crop utilization increased from 30.29\% to $43.52 \%$. The proportion of gaseous loss was

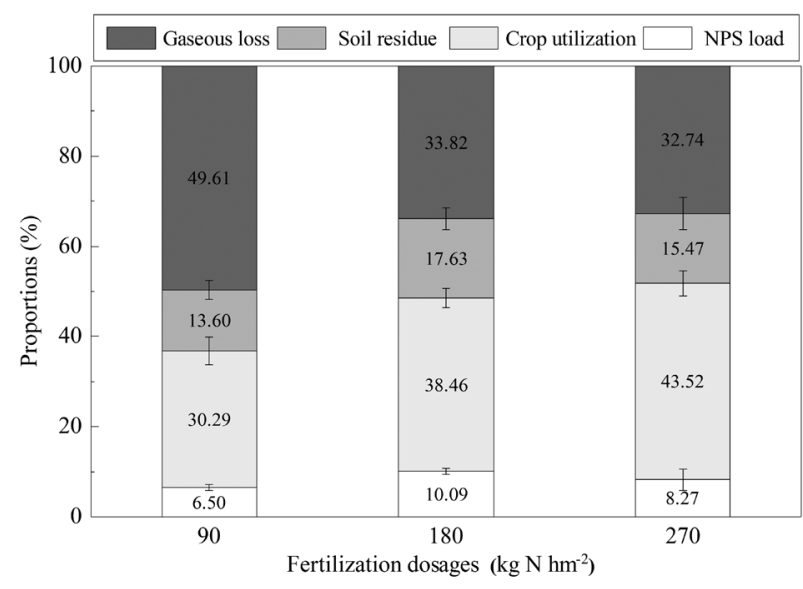

Fig. 8. The $\mathrm{N}_{\mathrm{dff}}$ fates under different fertilization dosages. Values represent the mean of three replicates and error bars represent standard deviations.

inhibited from $49.61 \%$ to $32.74 \%$, especially when the fertilization dosage increased from $90 \mathrm{~kg} \mathrm{~N} \mathrm{hm}^{-2}$ to $180 \mathrm{~kg} \mathrm{~N} \mathrm{hm}^{-2}$. Ghoneim et al. (2006) found that about $30 \%$ of $\mathrm{N}$ loss was through the $\mathrm{NH}_{3}$ volatilization [43]. Therefore, it could be inferred that the gaseous loss might be mainly $\mathrm{NH}_{3}$ volatilization. Although the increase of fertilization dosages did not substantially heighten the proportion of NPS load (with average value of $\sim 8.3 \%$ ), it exacerbated the amount of NPS load. For example, the $\mathrm{N}_{\text {dff }}$ loss from NPS under fertilization dosage of $270 \mathrm{~kg} \mathrm{~N} \mathrm{hm}^{-2}$ was $22.33 \mathrm{~kg} \mathrm{~N} \mathrm{hm}^{-2}$, which was $22.94 \%$ greater than that under fertilization dosage of $180 \mathrm{~kg} \mathrm{~N} \mathrm{hm}^{-2}$. Previous studies stated the similar result [18,19,45-48]. Therefore, for NPS reduction, the control of fertilization dosage is recommended. Ghoneim et al. (2006) reported that only $6.2 \%$ of $\mathrm{N}_{\text {dff }}$ remained in soil, which was much lower than the result observed in this study. The different results might be caused by multiple factors, e.g., climate, fertilizer types, soil types and paddy cultivars, etc. [43].

\section{Conclusions}

The fate of fertilizer nitrogen in paddy rice field was investigated via ${ }^{15} \mathrm{~N}$ isotope technology. The main conclusions were as follows: 1 . Increasing fertilization dosages would cause a drastic increase of $\mathrm{N}_{\text {dff }}$ concentration in paddy field water within a short time. The critical period for NPS pollution control was the first five days after fertilization. 2. Seventy percent of annual TN output load was sourced from the $\mathrm{N}_{\mathrm{dff}}$ in the current year. 3. The $\mathrm{N}_{\mathrm{dff}}$ contents in paddy tissues increased with increasing fertilization dosages. 4 . The majority of residual $\mathrm{N}_{\text {dff }}$ was distributed in the top soil layer $(0-10 \mathrm{~cm}) .5$. Crop utilization and gaseous loss were the main fates of the $\mathrm{N}_{\text {dff }}$ Although the increase of fertilization dosages enhanced the crop utilization 
rate and decreased the proportion of other fates, higher fertilization dosages exhibited higher amounts of NPS load, and $180 \mathrm{~kg} \mathrm{~N} \mathrm{hm}^{-2}$ are optimum in practical rice cultivation from the overall consideration of nitrogen utilization rate and NPS control.

\section{Acknowledgements}

This work was funded by the National Natural Science Foundation of China (No. 41471406), the National Key R\&D Program of China (No. 2016YFC0500404-4) and the Youth Innovation Promotion Association of CAS (No. 2017274).

\section{Conflict of Interest}

The authors declare no conflict of interest.

\section{References}

1. YAO H., LEHNDORFF E., AMELUNG W., WASSMANN R., ALBERTO, M.C., UNOLD G.V., SIEMENS J. Drainage and leaching losses of nitrogen and dissolved organic carbon after introducing maize into a continuous paddy-rice crop rotation. Agriculture, Ecosystems \& Environment. 249, 91, 2017.

2. Food and Agriculture Organization of the United Nations (FAO) Statistical Databases. Available online: http://www. fao.org/faostat/en/\#data/QC/visualize (accessed on 10 October 2018).

3. LI C., FARAHBAKHSHAZAD N., JAYNES D.B., DINNES D.L., SALAS W., MCLAUGHLIN D. Modeling nitrate leaching with a biogeochemical model modified based on observations in a row-crop field in Iowa. Ecological Modelling. 196 (1-2), 116, 2006.

4. ZHANG H.X., SUN B., XIE X.L., ZHUANG S.Y. Simulating the effects of chemical and non-chemical fertilization practices on carbon sequestration and nitrogen loss in subtropical paddy soils using the DNDC model. Paddy \&Water Environment. 13 (4), 1, 2014.

5. International Fertilizer Association (IFA). Fertilizer Use by Crop Report, Available online: https://api.ifastat.org/ reports/download/120 (accessed on 10 October 2018).

6. DOBERMANN A., CASSMAN K.G. Plant nutrient management for enhanced productivity in intensive grain production systems of the United States and Asia. Plant\& Soil. 247 (1), 153, 2002.

7. ZHANG Y., XU W., DUAN P., CONG Y., AN T., YU N., ZOU H., DANG X., AN J., FAN Q., ZHANG Y. Evaluation and simulation of nitrogen mineralization of paddy soils in Mollisols area of Northeast China under waterlogged incubation.. Plos One. 12(2), e0171022, 2017.

8. CASSMAN K.G., DOBERMANN A., WALTERS D.T. Agroecosystems, nitrogen-use efficiency, and nitrogen management. Ambio. 31 (2), 132, 2002.

9. YANG S., PENGS., XU J., HOU H., GAO X. Nitrogen Loss from Paddy Field with Different Water and Nitrogen Managements in Taihu Lake Region of China. Communications in Soil Science \&Plant Analysis. 44 (16), 2393, 2013.
10. LIANG X.Q., CHEN Y.X., LI H., TIAN G.M., NI W.Z., HE M.M., ZHANG Z.J. Modeling transport and fate of nitrogen from urea applied to a near-trench paddy field. Environmental Pollution. 150 (3), 313, 2007.

11. SMITH K.A., JACKSON D.R., PEPPER T.J. Nutrient losses by surface run-off following the application of organic manures to arable land. 1. Nitrogen. Environmental Pollution. 112 (1), 53, 2001.

12. ZHU H., YAN B.X., KHAN S. Nitrogen loss through lateral seepage from paddy fields: A case study in Sanjiang Plain, Northeast China. Journal of Food Agriculture \& Environment. 11 (1), 841, 2013.

13. GAO S., YU S., SHAO G., SHE D., WANG M., GUO R., CAO R., YAN S., DING J. Effects of Controlled Irrigation and Drainage on Nitrogen and Phosphorus Concentrations in Paddy Water. Journal of Chemistry. 2, $1,2016$.

14. XU J., PENG S., YANG S., WANG W. Ammonia volatilization losses from a rice paddy with different irrigation and nitrogen managements. Agricultural Water Management. 104 (2), 184, 2012.

15. ZHENG S.I., XIAO M., MIAO Z. Nitrogen Losses in Paddy Field Drainage Modified by Different Water Level Regulations. Pollish Journal of Environmental Studies. 26 (3), 1393, 2017.

16. HOU X., ZHOU F., LEIP A., FU B., YANG H., CHEN Y., GAO S., SHANG Z., MA L. Spatial patterns of nitrogen runoff from Chinese paddy fields. Agriculture Ecosystems \& Environment. 231, 246, 2016.

17. GUO W., FU Y., RUAN B., GE H., ZHAO N. Agricultural non-point source pollution in the Yongding River Basin. Ecological Indicators. 36, 254, 2014.

18. LE C., ZHA Y., LI Y., SUN D., LU H., YIN B. Eutrophication of Lake Waters in China: Cost, Causes, and Control. Environmental Management. 45 (4), 662, 2010.

19. LIUX., ZHANG F. Nitrogen fertilizer induced greenhouse gas emissions in China. Current Opinion in Environmental Sustainability. 3 (5), 407, 2011.

20. ONGLEY E.D., XIAOLAN Z., TAO Y. Current status of agricultural and rural non-point source Pollution assessment in China. Environmental Pollution. 158 (5), 1159, 2010.

21. YANG Y., YAN B.X., SHEN, W. Assessment of point and nonpoint sources pollution in Songhua River Basin, Northeast China by using revised water quality model. Chinese Geographical Science. 20 (1), 30, 2010.

22. YANG X.R., LI H., NIE S.A., SU J.Q., WENG B.S., ZHU G.B., YAO H.Y., GILBERT J.A., ZHU Y.G. Potential Contribution of Anammox to Nitrogen Loss from Paddy Soils in Southern China. Applied \& Environmental Microbiology. 81 (3), 938, 2015a.

23. ZHANG Z.S., CHEN J., LIU T.Q., CAO C.G., LI C.F. Effects of nitrogen fertilizer sources and tillage practices on greenhouse gas emissions in paddy fields of central China. Atmospheric Environment. 144, 274, 2016.

24. ZHONG Y., WANG X., YANG J., ZHAO X., YE X. Exploring a suitable nitrogen fertilizer rate to reduce greenhouse gas emissions and ensure rice yields in paddy fields. Science of Total Environment. 565, 420, 2016.

25. SHAO G.C., WANG M.H., YU S.E., LIU N., XIAO M., YUAN M. Potential of Controlled Irrigation and Drainage for Reducing Nitrogen Emission from Rice Paddies in Southern China. Journal of Chemistry. 5, 1, 2015.

26. JI X., ZHENG S., SHI L., LIU Z. Systematic Studies of Nitrogen Loss from Paddy Soils Through Leaching in 
the Dongting Lake Area of China. Pedosphere. 21 (6), 753, 2011.

27. SOLOMON A., KAZUYUKI I. Comparative effects of application of coated and non-coated urea in clayey and sandy paddy soil microcosms examined by the $15 \mathrm{~N}$ Tracer Technique. Soil Science \& Plant Nutrition. 50 (2), 215, 2004.

28. GHONEIM A., UENO H., EBID A., ASAGI N., ABOU EI DARAG I. Analysis of Nitrogen Dynamics and Fertilizer Use Efficiency in Rice Using the Nitrogen15 Isotope Dilution Method Following the Application of Biogas Slurry or Chemical Fertilizer. International Journal of Soil Science. 3 (1), 11, 2008.

29. KADIYALA M.D.M., MYLAVARAPU R.S., LI Y.C., REDDY G.B., REDDY K.R., REDDY M.D. Uptake efficiency of $15 \mathrm{~N}$-urea in flooded and aerobic rice fields under semi-arid conditions. Paddy\& Water Environment. 13 (4), 545, 2015.

30. KOZO M., NOBUFUMI M., SHIGEKAZU Y. Kinetics of 15N-Labelled Nitrogen from Co-Compost Made from Cattle Manure and Chemical Fertilizer in a Paddy Field. Soil Science \& Plant Nutrition. 46 (2), 355, 2000.

31. LEE J., CHOI H.L. The dynamics of nitrogen derived from a chemical nitrogen fertilizer with treated swine slurry in paddy soil-plant systems. Plos One. 12 (3), e0174747, 2017.

32. MULHOLLAND P.J., TANK J.F., SANZONE D.M., WOLLHEIM W.M., PETERSON B.J., WEBSTER J.R., MEYER J.L. Nitrogen cycling in a forest stream determined by a $15 \mathrm{~N}$ tracer addition. Ecological Monographs. 70 (3), 471, 2000.

33. ASAGI N., UENO H. Nitrogen dynamics in paddy soil applied with various $15 \mathrm{~N}$-labelled green manures. Plant\&Soil. 322 (1-2), 251, 2009.

34. YANG S., PENG S., XU J., HE Y., WANG Y. Effects of water saving irrigation and controlled release nitrogen fertilizer managements on nitrogen losses from paddy fields. Paddy\&Water Environment. 13 (1), 71, 2015b.

35. HUANG H., LIU C., CHEN S., CHEN J. Analysis of percolation and seepage through paddy bunds. Journal of Hydrology. 284 (1), 13, 2003.

36. YOH M., GOU Y., WANG D., YAN B.X. Biogeochemical behaviors of dissolved iron in Sanjiang Plain, China: discharge, chemical forms, and year-to-year variation. Report on Amur-Okhostsk project No.5. Japan: Research Institute for Humanity and Nature. 53, 2008.

37. SUN Z., MOU X., LI X., WANG L., SONG H., JIANG H. Application of Stable Isotope Techniques in Studies of Carbon and Nitrogen Biogeochemical Cycles of
Ecosystem. Chinese Geographical Science. 21 (2), 129, 2011.

38. ZHAO Z., ZHANG H., LI C., ZHAO Q., CAO L. Quantifying nitrogen loading from a paddy field in Shanghai, China with modified DNDC model. Agriculture Ecosystems \& Environment. 197, 212, 2014.

39. LIANG X.Q., LI H., CHEN Y.X., HE M.M., TIAN G.M., ZHANG Z.J. Nitrogen loss through lateral seepage in neartrench paddy fields. Journal of Environmental Quality. 37 (2), 712, 2008.

40. PENG S.Z., YANG S.H., XU J.Z., LUO Y.F., HOU H.J. Nitrogen and phosphorus leaching losses from paddy fields with different water and nitrogen managements. Paddy \&Water Environment. 9 (3), 333, 2011.

41. JANSSEN M., LENNARTZ B. Characterization of Preferential Flow Pathways through Paddy Bunds with Dye Tracer Tests. Soil Science Society of America Journal. 72 (6), 1756, 2008.

42. CHEN S., LIU C. Analysis of water movement in paddy rice fields (I) experimental studies. Journal of Hydrology. 260 (1-4), 206, 2002.

43. GHONEIM A., UENO H., EBID A. Nutrients Dynamics in Komatsuna (Brassica campestris L.) Growing Soil Fertilized with Biogas Slurry and Chemical Fertilizer Using 15N Isotope Dilution Method. Pakistan Journal of Biological Sciences. 9 (13), 2426, 2006.

44. CHEN G., CHEN Y., ZHAO G., CHENG W., GUO S., ZHANG H., SHI W. Do high nitrogen use efficiency rice cultivars reduce nitrogen losses from paddy fields? Agriculture Ecosystems \& Environment. 209, 26, 2015.

45. XING G.X., ZHU Z.L. An assessment of $\mathrm{N}$ loss from agricultural fields to the environment in China. Nutrient Cycling in Agroecosystems. 57 (1), 67, 2010.

46. MONAGHAN R.M., PATON R.J., SMITH L.C., DREWRY J.J., LITTLEJOHN R.P. The impacts of nitrogen fertilisation and increased stocking rate on pasture yield, soil physical condition and nutrient losses in drainage from a cattle grazed pasture. New Zealand Journal of Agricultural Research. 48 (2), 227, 2005.

47. YIN F., FU B., MAO R. Effects of nitrogen fertilizer application rates on nitrate nitrogen distribution in saline soil in the Hai River Basin, China. Journal of Soils \& Sediments. 7 (3), 136, 2007.

48. TAO Z., CHEN A., JIAN L., HONGBIN L., BAOKUN L., LIMEI Z., DAN Z., HONGYUAN W. Cropping systems affect paddy soil organic carbon and total nitrogen stocks (in rice-garlic and rice-fava systems) in temperate region of southern China. Science of Total Environment. 609, 1640, 2017. 